\title{
The Mangarevan Sequence and Dating of the Geographic Expansion into Southeast Polynesia
}

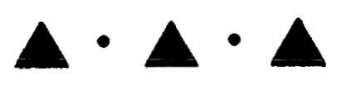

\author{
ROBERT C. GREEN AND MARSHALL I. WEISLER
}

IN RELATiOn TO Other ARChipelagoes in East Polynesia, the archaeology of the Mangarevan group is not particularly well known. The group consists of a cluster of small high islands, plus motu and sand cays, on an encircling reef, all encompassed within a lagoon some $25 \mathrm{~km}$ across (Fig. 1). This is usually called Mangareva after its principal volcanic island remnant. The other member of the group is Temoe Atoll, $40 \mathrm{~km}$ to the east, once occupied by people from Mangareva, but in this century largely deserted. The initial archaeological investigations of the group's surface structures were conducted by K. P. Emory of the Bernice P. Bishop Museum and published in 1939. Twenty years later under the sponsorship of the American Museum of Natural History, Robert C. Green conducted nearly six months of archaeology in Mangareva, and especially on the island of Kamaka. Only unpublished manuscripts in limited circulation on his work have been available until recently.

In the period 1990-1992, the second author, Weisler (1996a:618), surveyed additional sites on the islands of Mangareva lagoon, focusing particularly on coastal middens and rock sources for stone tool manufacture overlooked by Emory and Green. In 1992 he also surveyed and mapped most archaeological features on Temoe Atoll, some of them initially recorded by Emory. An overview of settlement data from all sources appeared in Weisler (1996b). These investigations formed a small part of a more general project in this part of Southeast Polynesia that involved intensive survey and excavations on the makatea island of Henderson, a survey and test excavations on Oneo Atoll, and, on the high island of Pitcairn, investigation of its isotropic adze rock and volcanic glass resources, as well as test excavations of a few habitation areas and colluvial sections indicating landscape change (Weisler 1994, 1995, 1998a). These three islands, including Ducie Atoll, which is devoid of any archaeological sites, are known as the Pitcairn group. Islands of both the Mangarevan and Pitcairn groups have been shown by archaeological sourcing studies to have been in continuous interaction with each

Robert C. Green is in the Department of Anthropology, University of Auckland, New Zealand, and Marshall Weisler is in the Department of Anthropology, University of Otago, Dunedin, New Zealand.

Asian Perspectives, Vol. 41, No. 2 (C) 2002 by University of Hawai'i Press. 


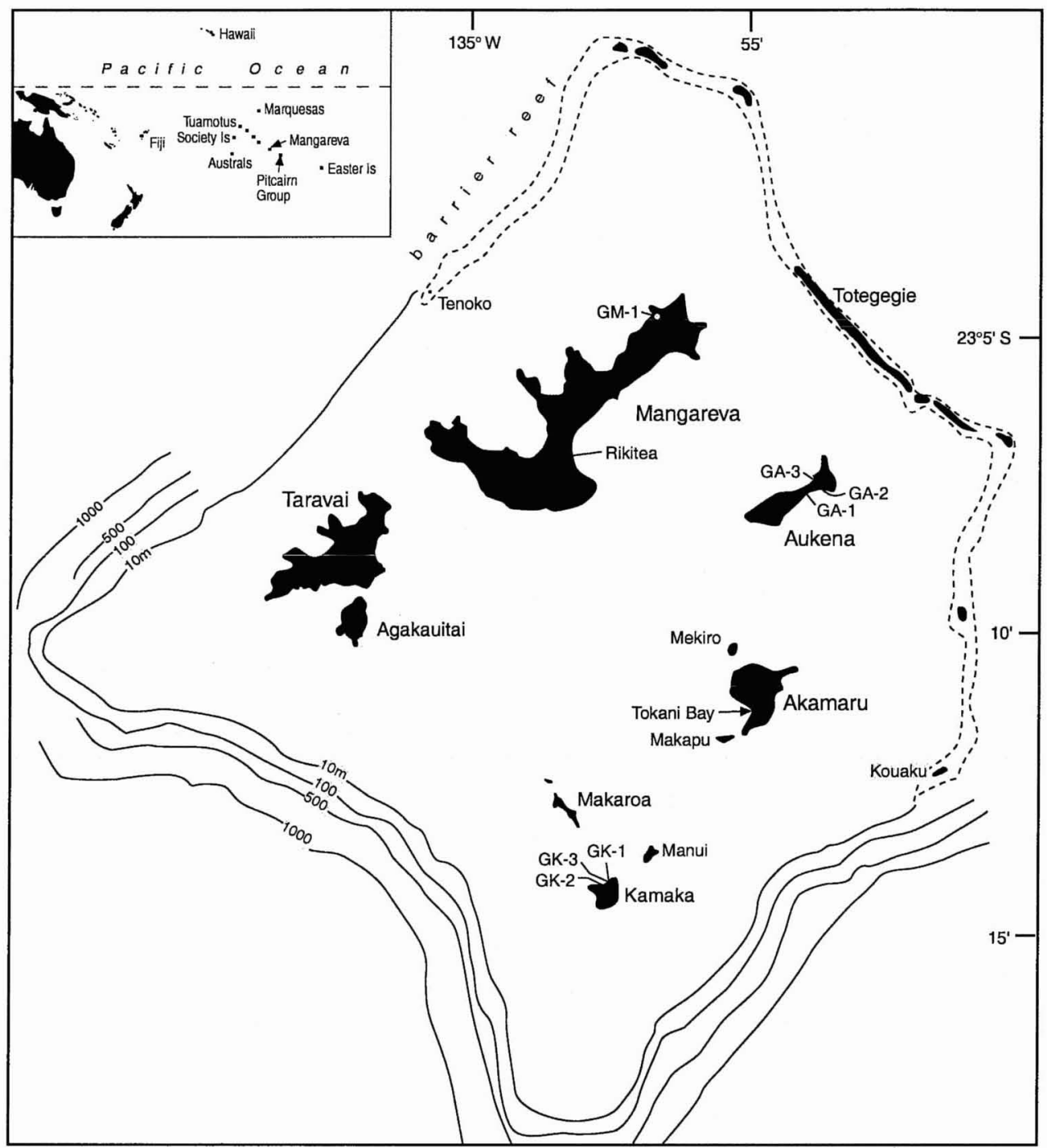

Fig. 1. The Mangareva group showing the location of archaeological sites and place-names mentioned in the text.

other from about A.D. 1000 to well into the sixteenth century (Weisler 1996a, 1997, 1998b).

In this paper we provide an overview of the Mangareva sequence constructed by correlating the stratigraphic layers from Green's excavations with temporal control provided by eight radiocarbon age determinations and changes in fishhooks (Green 1960; Weisler and Green n.d.) and adzes (Weisler and Green 2001) documented elsewhere. The Mangareva sequence as described here begins at A.D. 1200, at least 200-400 years after Mangareva artifacts (pearl shell, adze material, and vesicular basalt oven stones) appear in the archaeological record of Henderson 
Island (Pitcairn group). We believe that the details of the missing two to four centuries on Mangareva will help further define island relationships in Southeast Polynesia and should be an objective of future work in Mangareva.

At the time of Green's work in 1959, one of four kinds of sequence building now current in Polynesian archaeology was in vogue (Green 1993:224; Kirch $1982: 71-72,1989: 28-31)$. It was heavily oriented to the use of portable artifacts and stylistic changes in them over time. In East Polynesia this was especially true for adzes, fishhooks, and coral files (Emory et al. 1959; Green 1961; Suggs 1961). Another sequence-building approach then in use was the developmental one pioneered by Suggs (1961): Settlement, Developmental, Expansion, Classic, and Historic periods. The first strategy suited well Green's excavation findings in Mangareva; the second has proved of limited scope, and is not employed in this overview.

Another difficulty faced Green, once he had radiocarbon dates for the beginning of the excavation sequence he had constructed for Mangareva from the stratigraphy and stylistic changes in fishhooks, especially of line attachments and hook shape. His results appeared to be out of line with those of Suggs by nearly a millennium. Types of adzes, fishhooks, and other items Green recovered, dating to A.D. 1200 and thereafter, appeared in the Marquesas from 500 to 1000 years earlier. Since then Rolett $(1989,1992,1998)$ encountered precisely the same problem in his excavations at Hanamiai in the southern Marquesas. They have finally been resolved by reinvestigation of the supposedly much earlier Suggs' Marquesan site of Ha'atuatua showing that in large part the major prehistoric deposits there used to define the Settlement and Developmental periods in fact date to the A.D. twelfth century and after (Rolett and Conte 1995). Consequently, the Mangarevan material excavated by Green begins to make more sense, particularly when Weisler's efforts on Henderson containing 800-year-old items from Mangareva demonstrate that, in fact, Green failed to find deposits belonging to the first 200400 years of its sequence.

\section{CONTEXT FOR ARCHAEOLOGICAL EXCAVATIONS}

From the nineteenth- and twentieth-century ethnographies of Mangareva by Laval (1938) and Buck (1938), one can sketch the settlement pattern of that island group during the time of initial contacts with Europeans (Green 1967:115-119) combining that information with the 1960 data of Green and that of Emory (1939). This is just as well, because none of the major monumental architecture at the time of Emory's survey remained except on the adjacent abandoned atoll of Temoe. Instead, through the mid-nineteenth-century conversion efforts of Laval and other Catholic missionaries who followed, they transformed the scene in physical layout and architecture to one based on a wholly European model, destroying in the process all of the substantial marae, except an excavated example on Kamaka and those on Temoe Atoll. Green's map of the probably pre- to just post-contact settlement at Tokani Bay on the island of Akamaru also gives an archaeological hint of an earlier pattern. (See Green and Weisler 2000: Fig. 2 and Appendix 1.) His summary of the presumed contact period settlement pattern of the 1820 s to 1830 s as understood from the ethnographic sources supplemented by and correlated with such archaeological data as were then available. Thus, it serves 
as a necessary contextual background to the excavation results, derived as they are almost entirely from stratified cave sites.

Previous surface survey and very limited "digging” (Emory 1939:30) provided little data on possible sites suitable for more intensive investigation, especially as the general destruction of field monuments recorded on the main islands did not encourage their excavation. Because of its isolation at the southern end of the lagoon, the small island of Kamaka was relatively undisturbed by activities of the historic period and from an examination of the beach deposits and the sizeable rockshelters at the rear of the beach, archaeological deposits were located with obvious excavation potential.

The results of Green's 1959 excavations at Kamaka proved to be excellent, yet they suggested that initial habitation on the island had been of an impermanent nature and largely concerned with fishing. For evidence of other occupation in the island group, or of more permanent forms of settlement containing artifacts reflecting other forms of activity, it would be necessary to concentrate on the four main islands. At the end of a three-week archaeological survey, three sites were selected for study. Additionally, as noted above, a contact settlement complex in Tokani Bay, Akamaru Island, was cleared and mapped (Green and Weisler 2000: Fig. 2).

A site on Aukena, Te Ana Pu (GA-1), had been selected for the next excavation for the following reasons: (1) not only was it a large well-lit shelter in the narrow central ridge of the island (see Weisler 1996b: Fig. 2), but the back wall of the site had long ago been breached by erosion, providing inhabitants easy and obviously well-used access from one side of the island to the other; (2) the floor and front of the shelter were covered by relatively thick and undisturbed deposits containing abundant signs of human occupation including prehistoric artifacts; and (3) this was judged the best relatively restricted and well-defined occupation midden among those located during the survey.

Investigation of two other nearby sites was also undertaken at this time: the marae pavement of Tautoro (GA-3) and a small rockshelter along the cliffs to the northeast of the main cove (GA-2) (Fig. 1).

\section{EXCAVATIONS ON KAMAKA}

Of the three small high islands in the southeastern portion of the lagoon, Kamaka is by far the most suited to prolonged habitation. The rocky island is only 0.5 $\mathrm{km}^{2}$, rising to $166 \mathrm{~m}$ in elevation. Coastal relief is broken by two adjoining coves on the north side, behind which are shallow, cliff-lined embayments occupied by steeply rising white sand beaches. The main areas for pre-European habitation occur at the crest of these beaches and in the shelters along the cliffs behind. A coral fringing reef occupies the entire bay and supports an excellent fishing ground. The remainder of the coast drops precipitously into the sea.

In 1959, Kamaka was uninhabited and the vegetation was heavily grazed by a herd of feral goats, thus enormously increasing erosion. This is reflected in the excavation sections. The island lacks any permanent springs and precipitation also appears to be below that on the main island of Mangareva.

In traditional history Kamaka was known as the island of Mito, but it is not often referred to. Five generations before European contact (ca. A.D. 1725) when 


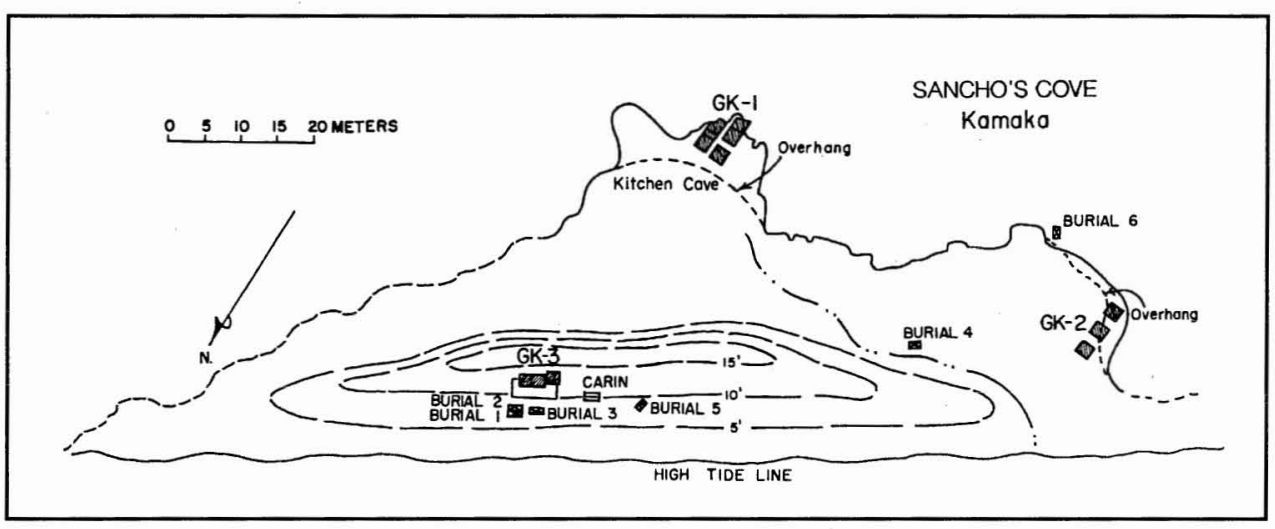

Fig. 2. The north coast of Kamaka showing the location of excavations and burials.

Te Oa proposed a division of land in Mangareva following his father's death, he took Kamaka for himself (Buck 1938:83). Again about A.D. 1750 Moria-tararoa, a warrior then living on the island with his followers, refused to support the 'akaariki of Mangareva, because in dividing the land all he had been given was Kamaka. As a consequence, he complained that his belly was filled with nothing but the legs of crabs from its rocky promontories, a clear allusion to its meager resources. Tradition, then, ascribes Kamaka a role as a rather undesirable island, one which is mentioned only in the later portion of the traditional history.

Prehistoric occupation remains on Kamaka were concentrated in the area of the eastern beach, Sancho's Cove, and all excavations centered there (Fig. 2). Along the beach front at a level well above disturbance by the sea, oven stones, charcoal-blackened sand, midden debris, and occasional artifacts were eroding from under the sterile white sand. In one place remains of a former stone structure lay partially exposed (see GK-3 below), presumably that described by Emory (1939:33-34). The rockshelters along the cliffs behind the beach, however, though suitable for habitation, exhibited no visible signs of a similar occupation. Finally, despite previous reports of scattered human bones along the beach front and in some cave shelters, none were encountered during the preliminary inspections. However, in the course of excavations on the beach front, as well as in one cave, 11 burials were found, carefully exposed, and recorded. Two rockshelters and the main architectural structure on the beach crest were excavated. Figure 2 shows the location of these sites at Sancho's Cove on the north coast of the island of Kamaka.

\section{GK-1}

Located at the rear of Sancho's Cove at the base of the cliffs, this rockshelter measures $14 \mathrm{~m}$ wide and $6 \mathrm{~m}$ deep inside the dripline providing nearly $80 \mathrm{~m}^{2}$ of protected space. Five 2 -by-2-m squares and two intervening baulks were excavated (Fig. 3). Clearly defined stratigraphic deposits were usually confined to the rear of the shelter, while toward the open central area, successive digging of oven depressions and other pits, by the occupants, had disturbed most overall strati- 


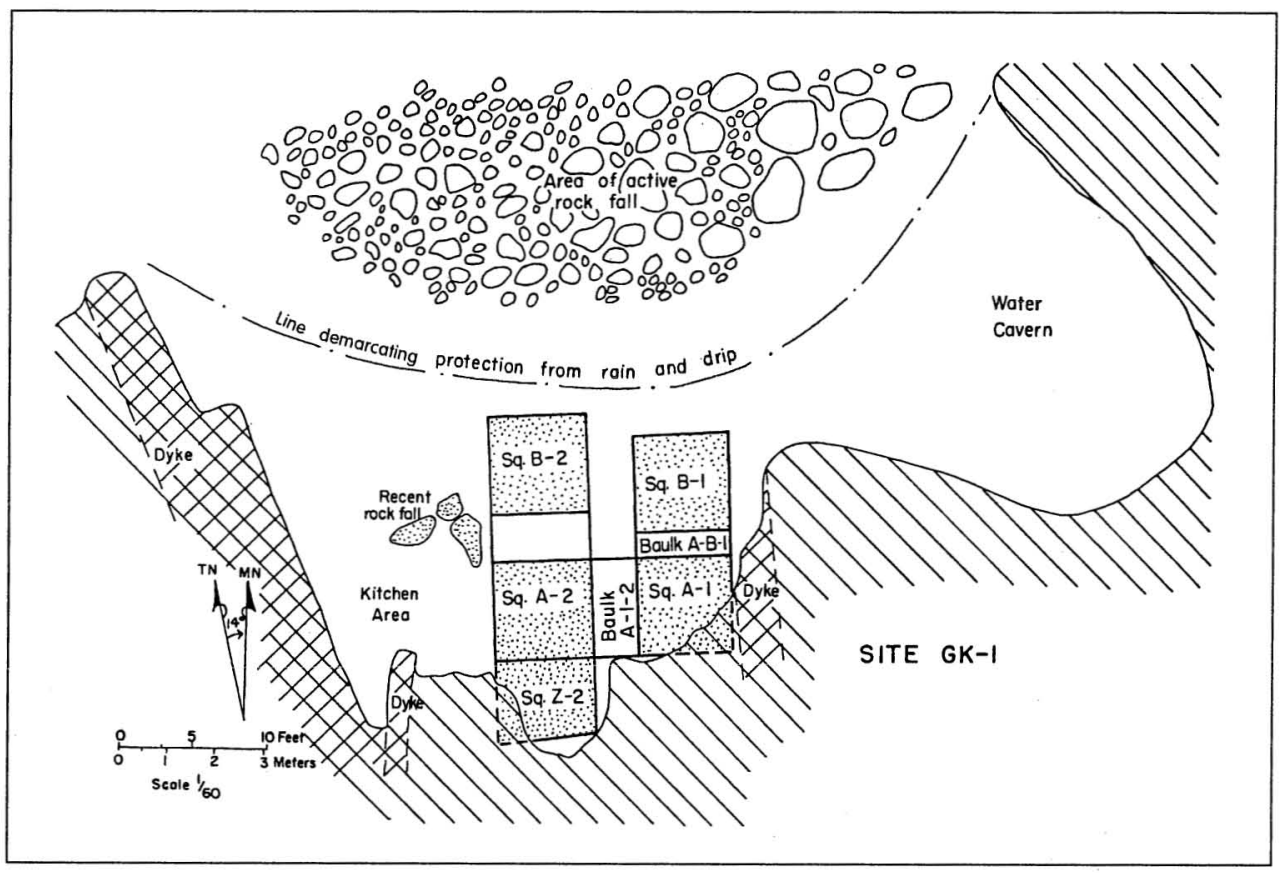

Fig. 3. GK-1, showing grid layout used in its excavation.

graphic regularities. Fortunately, Squares A-1, A-2, and Z-2, which lie to the rear of the shelter and contain the most clearly defined deposits, also yielded the majority of the portable artifacts.

The initial occupation of GK-1 began with Layer J (Beds 1-4), which was poorly represented, primarily because of later disturbances but also because occupation was intermittent and probably not of great intensity. While the layer consisted of four beds, only 1 and 2 extended over a large area, and portable artifacts were restricted to Bed 2. The main structural features from this period were postholes, probably indicating the construction of additional protective structures within the overhang, shallow fire pits, pits, and an oven. A charcoal sample from one of the firepits excavated into the underlying cave silt produced a radiocarbon age determination of $760 \pm 80$ B.P., placing the initial occupation between the mid-twelfth and early fifteenth century A.D. (sample I-190). A second date from another fire pit at the base of the deposits defines this initial activity as occurring in the eleventh to thirteenth century A.D. (Beta-109018; Fig. 4). These dates, and those that follow, were calibrated after Stuiver and Reimer (1993) using the decadal tree-ring data set to 6000 cal B.C. for terrestrial samples. Forty years were subtracted from the mean of conventional dates as well as from the ${ }^{14} \mathrm{C}$ mean for the isotopes values to correct for southern hemisphere samples, and calibrations reported at 2 -sigma (Table 1 ).

Layer I (Beds 5-7), a sandy loam, included scattered firepits, ovens, and occasional natural beachrock slabs from the beach. The layer also produced a fair quantity of portable artifacts. It is dated to the thirteenth to fifteenth century A.D. (Beta-109016). 
Table i. Radiocarbon Age Determinations from Mangareva

\begin{tabular}{|c|c|c|c|c|c|c|c|c|}
\hline SAMPLE NO. & SITE & $\begin{array}{l}\text { SQUARE/ } \\
\text { LAYER }\end{array}$ & ${ }^{14} \mathrm{C}$ AGE B.P. & ${ }^{13} \mathrm{C} /{ }^{12} \mathrm{C}$ & $\begin{array}{l}\text { DNENTIONA } \\
\text { AGE B.P. }\end{array}$ & WEIGHT (g) & CONTEXT & CALIBRATED $2 \sigma^{\mathrm{a}}$ \\
\hline Beta-109017 & GK-1 & $\mathrm{A}-1 / \mathrm{C} 2$ & $200 \pm 50$ & -27.7 & $160 \pm 50$ & 37.8 & Oven & $\begin{array}{c}1666(1702,1724,1815 \\
1845,1986,1976 \\
1917,1954) 1955\end{array}$ \\
\hline I-191 & GK-1 & $\mathrm{Z}-2 / \mathrm{G}$ & $330 \pm 80$ & $\mathrm{n} / \mathrm{a}$ & $\mathrm{n} / \mathrm{a}$ & $\mathrm{n} / \mathrm{a}$ & NE quad., pit $C$, base of $G$ & $1440(1645) 1954$ \\
\hline Beta-109016 & GK-1 & $\mathrm{A}-1 / \mathrm{I}$ & $640 \pm 60$ & -25.4 & $640 \pm 60$ & 15.1 & Layer I & $\begin{array}{l}1284(1330,1346,1393) \\
1437\end{array}$ \\
\hline I-190 & GK-1 & $\mathrm{A}-1 / \mathrm{J}$ & $760 \pm 80$ & $\mathrm{n} / \mathrm{a}$ & $\mathrm{n} / \mathrm{a}$ & $\mathrm{n} / \mathrm{a}$ & $\begin{array}{l}\text { Fire pit, } 110 \mathrm{~cm}, \mathrm{SW} \text { corner } \\
\text { of NE quad }\end{array}$ & $1162(1286) 1409$ \\
\hline Beta-109018 & GK-1 & $\mathrm{A}-1 / \mathrm{J}$ & $860 \pm 60$ & -25.3 & $850 \pm 60$ & 6.6 & $\begin{array}{l}\text { Fire pit, } 170 \mathrm{~cm}, \mathrm{SW} \text { corner, } \\
\text { base of site }\end{array}$ & $\begin{array}{l}1065(1224,1227,1245, \\
1257) 1294\end{array}$ \\
\hline Beta-109019 & GK-2 & B-I/G & $890 \pm 70$ & -25.3 & $880 \pm 70$ & 10.2 & Layer G & 1025 (1215) 1292 \\
\hline I-192 & GK-3 & $\mathrm{A}-1 / \mathrm{C} 2$ & -100 (modern?) & $\mathrm{n} / \mathrm{a}$ & $\mathrm{n} / \mathrm{a}$ & $\mathrm{n} / \mathrm{a}$ & $\begin{array}{l}\text { Directly under pavement, } \\
\text { third level }\end{array}$ & \\
\hline I-193 & GA-1 & $\mathrm{B}-1 / \mathrm{C}$ & $520 \pm 80$ & $\mathrm{n} / \mathrm{a}$ & $\mathrm{n} / \mathrm{a}$ & $\mathrm{n} / \mathrm{a}$ & Charcoal lens, just above floor & 1304 (1436) 1635 \\
\hline
\end{tabular}

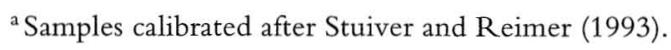




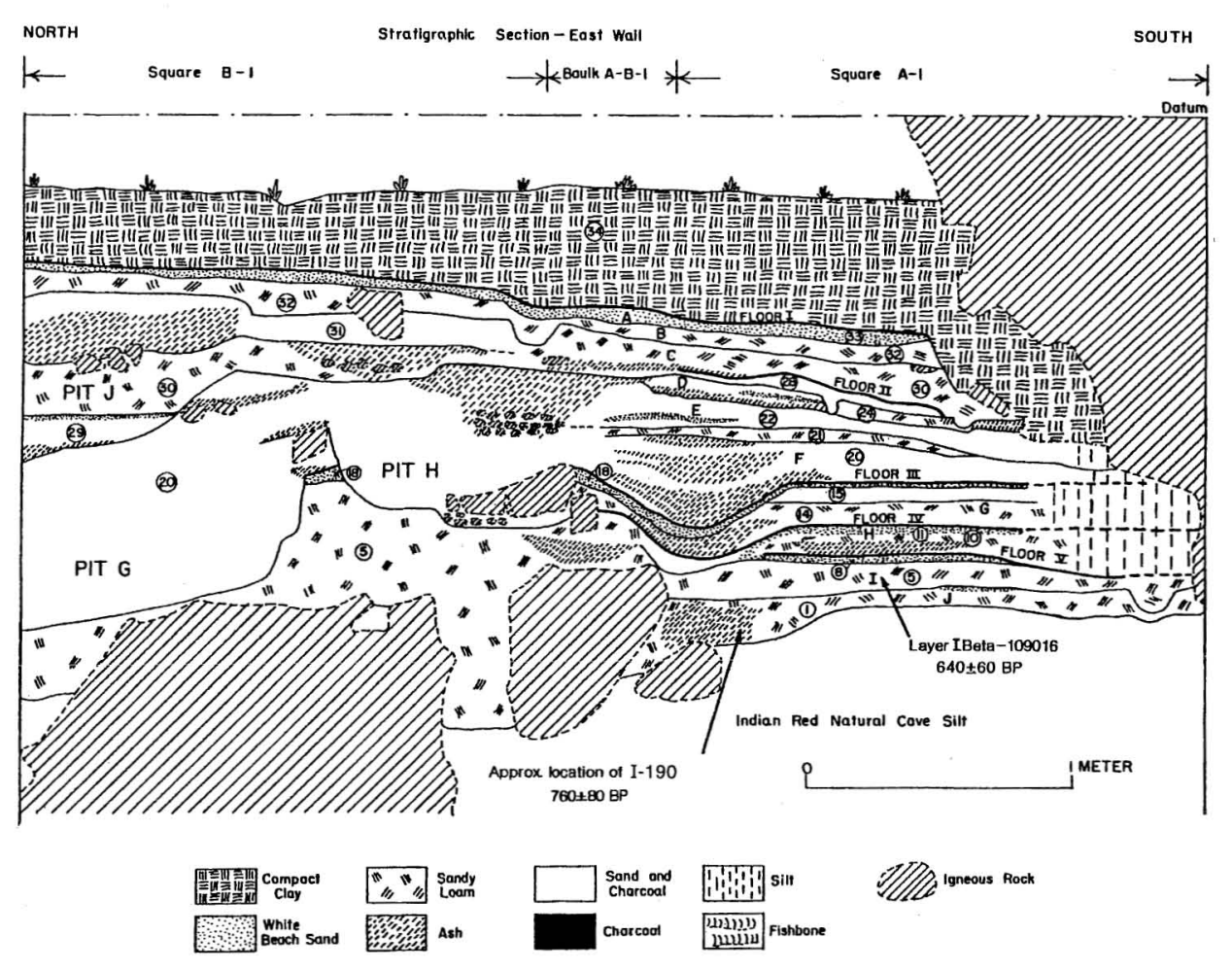

Fig. 4. East profiles of Squares B-1 to A-1 at rockshelter GK-1, Kamaka Island, Mangareva.

Along the rear portion of the shelter, Layer I was capped by Bed 8, or Sand Floor V, the first of five such sand floors (Fig. 4). At this time a number of basalt and beachrock slabs were set into this floor to serve as a rudimentary pavement.

Accumulation of a midden deposit on Sand Floor $\mathrm{V}$ comprised Layer $\mathrm{H}$ and suggested that only a short interval was involved before another sand floor, IV (Bed 11), was spread over previous deposits. Two pits and beachrock slabs outlining walls for two bounded habitation spaces were encountered and marks the first indications of more permanent habitation at the site, rather than simply overnight camping by fishing parties.

The sandy loam of Layer G (Beds 14-17), represents a period of intensive and widespread midden deposition in the shelter and is the first evidence for more permanent habitation in the form of structural evidence that is followed by extensive occupation debris containing numerous portable artifacts. On archaeological evidence discussed below, this began in the seventeenth century (A.D. 1645; Table 1, sample I-191), and continued over the next 200 years.

In the meager traditional history for Kamaka previously discussed, occupation was not mentioned until the beginning of the early eighteenth century, thus suggesting general support for the archaeological evidence that significant occupation is late, which on any assessment of the island's potential and its attractiveness to settlement, was to be expected.

Study of the sections (Fig. 4) also supports the view that the more intensive 


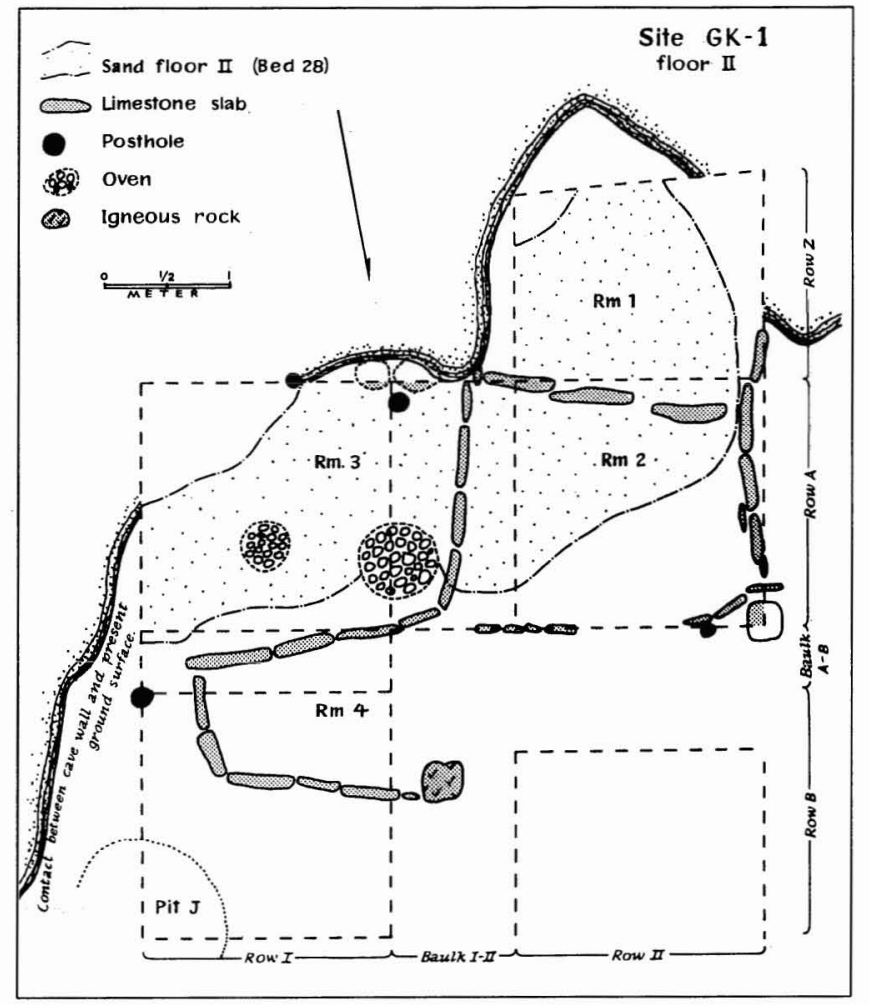

Fig. 5. Plans of excavations at GK-1, Kamaka Island, showing structural features and ovens at the base of Sand Floor II.

occupation was from the seventeenth century on if the radiocarbon age determinations are representative. Approximately two-thirds of the cultural deposits accumulated in the last 200 years, while the lower third may have taken up to 400 or more years to do so. Numerous pits, firepits, ash lenses, and ovens attest to considerable occupation activity during this shorter late period. In Layer F (Beds 19-21), a higher frequency of fire pits and ash lenses was encountered than in previous layers, indicating increased habitation activity. A similar picture emerges from Layers E and D, represented by Beds 22 and 24, respectively.

The final, most formal, and probably permanent occupation of the shelter during the prehistoric period, was that designated as Sand Floor II (Bed 28). At this time natural stone slabs, serving as curbs, were used to outline four "rooms" within the excavated portion of the overhang (Fig. 5). This occupation may correspond to that attributed to Moria-tararoa and his followers, which tradition places as ca. A.D. 1750 .

Midden accumulation after the construction of these structures was extensive. Layer C, which was directly associated with the spaces outlined by the beachrock curbs, was entirely prehistoric. Though interpretation of ${ }^{14} \mathrm{C}$ dates from the last 300 years is problematic due to fluctuations in the calibration curve, Beta-109017, with an age of between the seventeenth century and the present, is an indication that one of its eighteenth or early nineteenth-century intercepts is probably a reasonable choice. Layer B, however, contained some European materials along with prehistoric artifacts. Also, the loam of Layer B contained sufficient cave silt 
to give it a distinctly reddish cast suggesting that the shelter was unused for a time so that sediments from the cave walls could accumulate undisturbed by human activities.

Sand Floor I (Bed 33) is dated to the European contact period by the portable artifacts in Layer B. Local tradition among the Mangarevans says that the shelter was once used during the Mission period by people gathering beachrock slabs from the shore for the Church's large-scale construction program. It is uncertain whether this story is true, but use of the shelter must have been for sleeping, as few signs of other domestic activity appeared above Floor I, which was one of the most extensive floors of any encountered. For the last hundred or so years this site has been largely abandoned and a thick layer of compact clay, Bed 34, accumulated due primarily to the extensive erosion caused by feral goats. At several points within Bed 34 in Square A-2 thin ash and sand bands were encountered, containing bottle glass and metal, reflecting overnight visits. These are designated as Layer A and belong to the period of later European contact.

From this site, then, a not unexpected picture of habitation emerges, as one would surmise from the small size and isolated position of Kamaka in the Mangarevan group. During initial settlement of the main Mangarevan islands, Kamaka probably received little or no attention. When initial settlement stabilized and the population started to undertake fuller exploitation of the group's resources, periodic short-term expeditions to Kamaka for fishing and capturing sea birds began. These expeditions account for the earliest third of the cultural deposits and began as early as the eleventh century A.D. By the seventeenth or eighteenth century at the latest, population pressure on the main islands, which is well documented for the European contact period, had already begun to build up, making more permanent settlement on Kamaka likely for those with few other choices. Thus, for some, like the warrior Moria-tararoa, the first choice was Kamaka, a compromise in which one acquired land, although economic existence was still more or less dependent on the sea (Buck 1938:165).

\section{GK-2}

Along the cliff face at the western end of Sancho's Cove, in the promontory which divided the two beaches, a substantial overhang near the shore provided another protected shelter (Fig. 2). A stratigraphic section exposed by high waves revealed a deep midden deposit and a grid of 2-by-2-m squares with intervening $1-\mathrm{m}$ baulks was laid out in the most sheltered area (Fig. 2).

The first cultural layer, G (Beds 1 and 2), exhibited considerably less charcoal staining of sand than any of the overlying beds (Fig. 6). A less infrequent occupation like that encountered in the lower third of GK-1 is confirmed by the age for a basal charcoal sample (Beta-109019) dating to the eleventh to thirteenth century A.D. (Table 1).

The first deposit of white beach sand (Bed 4) was spread over the loam to create Floor 3 associated with a beachrock slab - the remnant of a probable structure. As in GK-1, the floor and slab probably represents the onset of more permanent habitation, which may correlate with Sand Floors IV or V at GK-1.

Layer D (Bed 6) occurred throughout the shelter and was heavily stained by charcoal and contained ovens and smaller firepits indicative of more intensive site 


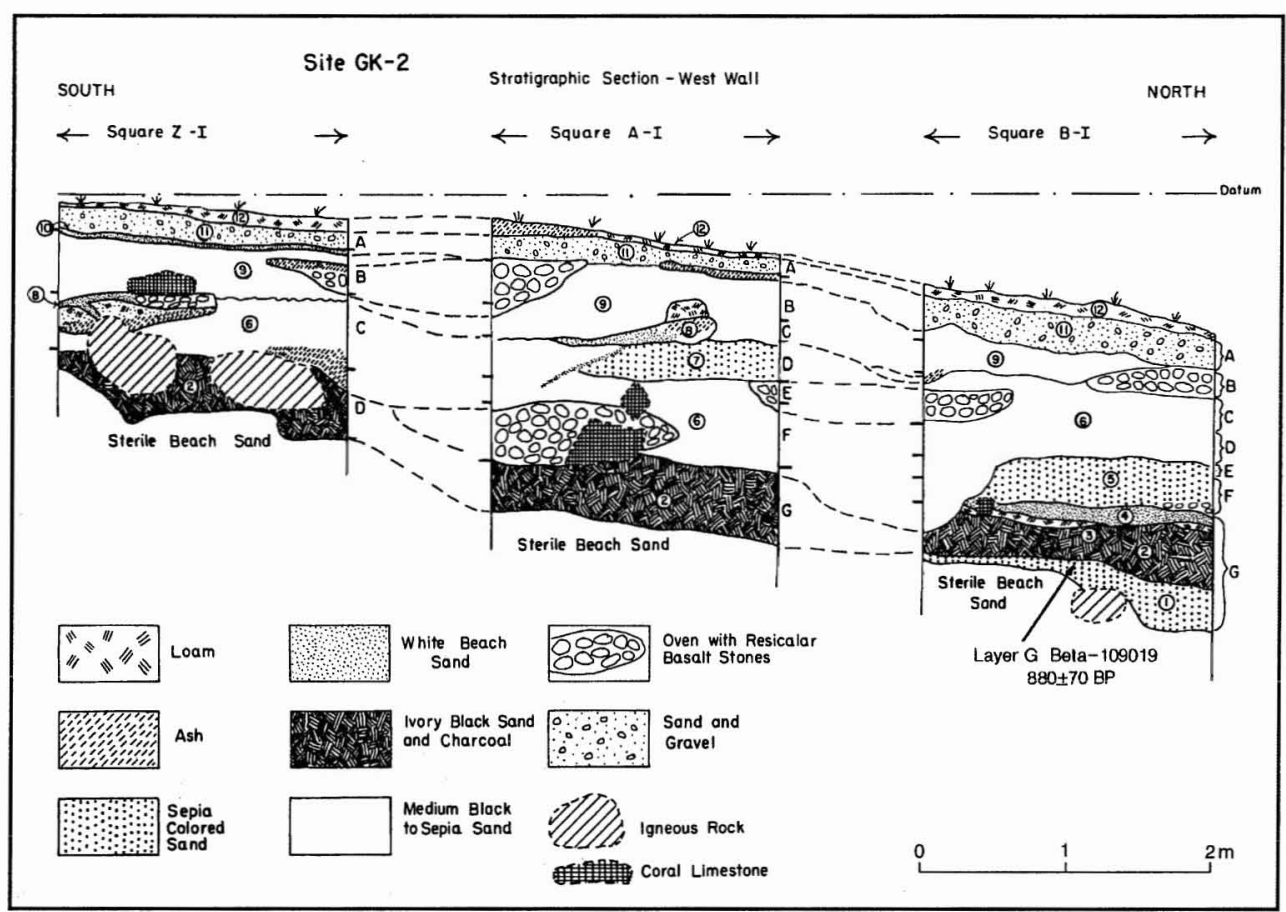

Fig. 6. West profiles of Squares Z-I, A-I, and B-I, site GK-2, Kamaka Island, Mangareva.

occupation. The change in deposition corresponds well to a similar change in the seventeenth century A.D. that began with Layer $G$ and continued thereafter at GK-1.

Deposition of white beach sand (Bed 8) marked the formation of Floor II, associated with beachrock slabs, which were subsequently sealed by an accumulation of midden designated as Layer B (Bed 9). As in the underlying Layer D, large ovens and smaller firepits indicated a continuation of the fairly intensive occupation begun in that period.

The uppermost bed (10) in the region of Square Z-1 is interpreted as Floor I, which consisted of beach sand associated with several beachrock slabs and two small storage pits. From its position in the sequence, it is likely contemporary with the elaborate structures of Floor II in GK-1 dating from the late eighteenth century. The midden, which accumulated on the GK-1 floor, was designated Layer A (Bed 11) and contained numerous small, naturally deposited stones from the shelter walls, suggesting that the site was abandoned (Bed 12) probably shortly after the time of European contact.

In summary, the stratigraphic sequence at GK-2 roughly parallels that at GK-1; basal radiocarbon age determinations are almost identical.

\section{GK-3}

This well-preserved stone structure is situated at the beach front where excavation of three 2-by-2-m squares revealed a midden deposit buried under $20-75 \mathrm{~cm}$ 


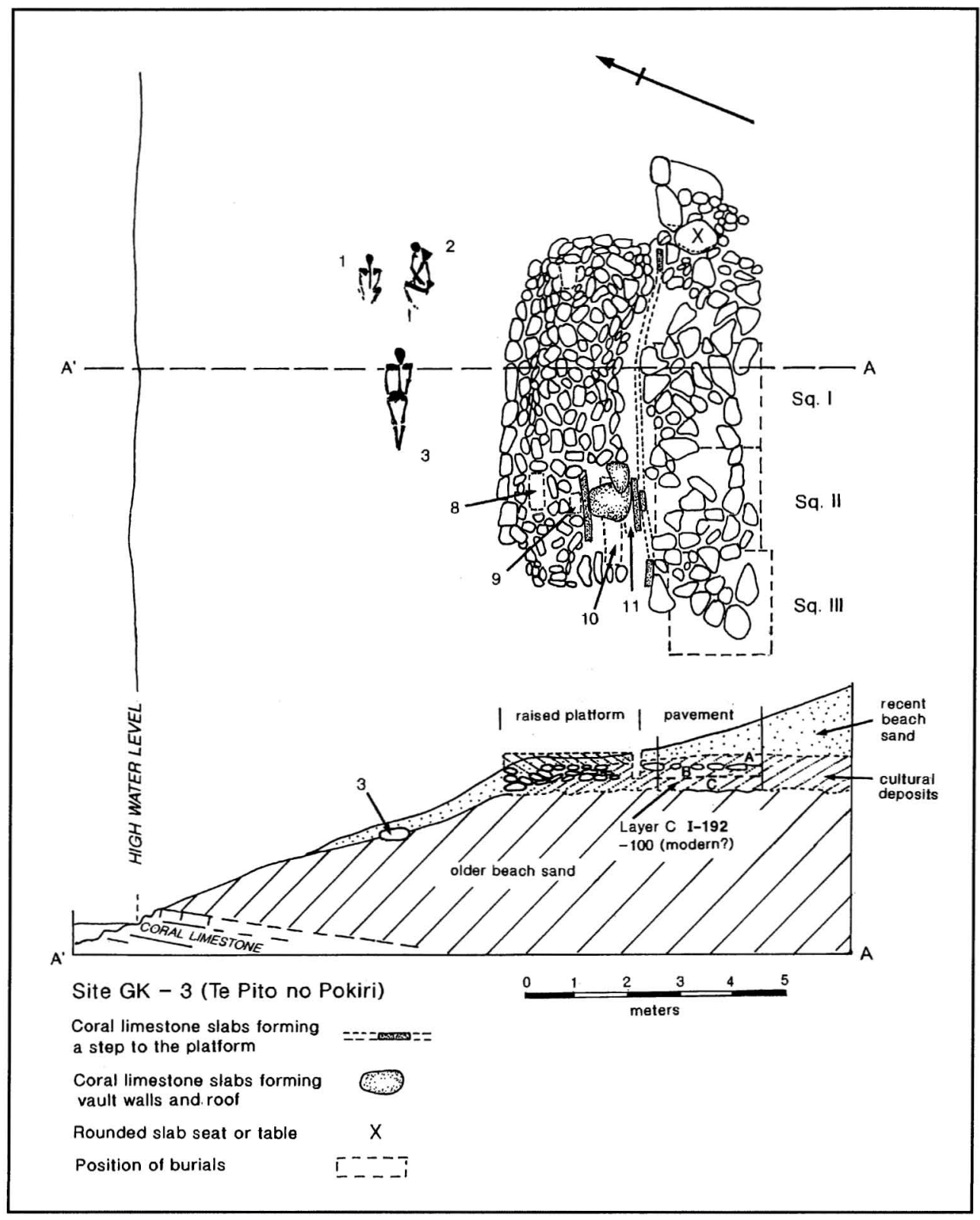

Fig. 7. GK-3 showing location of excavation squares, human burials-including one in a stonelined vault at the west end of the structure-and elevational cross section through Square I to the high-water level.

of recent wind-deposited beach sand. The uppermost cultural deposits, $10-25 \mathrm{~cm}$ thick, masked a pavement $2 \mathrm{~m}$ wide and $8 \mathrm{~m}$ long (Fig. 7). The layer overlying the pavement, but not the raised platform part of the structure, was designated Layer A.

Excavation revealed that the pavement was attached to the raised platform, of 
which only the lower portion remained undisturbed. The platform contained a cist-like vault with two burials. A number of other subadult burials were probably associated with the raised platform and others were simply buried within the sand in front.

There was no stratigraphic differentiation in the deposits below the pavement, although the sand became progressively less charcoal stained toward the base. Consequently, two arbitrary levels were established: Level B began immediately below the pavement to $15 \mathrm{~cm}$, Level $\mathrm{C}$ from $15-30 \mathrm{~cm}$ below the pavement. The underlying deposit was sterile beach sand.

A charcoal sample from just under the pavement provided a modern date of $<100$ B.P. (sample I-192; Table 1). The structure is clearly prehistoric, both in type and in materials recovered from Layer A above it; it could date between A.D. 1750 and 1840 at the latest, and thus contemporary with Sand Floor II of GK-1. Layer A above the pavement may date to the same period as Layer B of GK-1, that is, from the late prehistoric to the initial European contact period just before the rise of the Mission. Levels B and C, then, represent a short interval of time and their artifacts are all late in terms of the GK-1 sequence, and the period of fairly intensive occupation. In summary, Levels $\mathrm{B}$ and $\mathrm{C}$ have been assigned to the seventeenth and early eighteenth century, the structure to the later eighteenth century, and Layer A above it to the final period of prehistoric and initial historic contact on Kamaka.

\section{EXCAVATIONS ON AUKENA}

Aukena, the smallest of the four main islands, supported only five families as permanent inhabitants in 1959; in 1992, the island was only visited intermittently by residents of Rikitea. During the Mission period isolated stone houses occupied the narrow coastal flats on either side of the central portion of the island. Most of the population, however, was concentrated during the Mission period in a village associated with the school, Te Ana-o-tiki, on the southwestern side of the island, or around the Church of Saint Raphael in Purirau village on the narrow northwestern coast.

In 1834, at the end of the period of initial European contact and just before the first missionary success on the island, Aukena was fairly well explored by Moerenhout (1837:99). He described a concentration of low huts and a god house lying within a fertile valley on one side of the island. The adjacent extensive coastal flat toward the center of the island is where the largest landholding is known as Te Ana $\mathrm{Pu}$, a name for the nearby cave which gives access to the opposite coast. This coastal flat was covered with archaeological remains, among which, at the eastern end of the flat and close to the base of the ridge behind, was a large pavement. The Mangarevan guides, without prior questioning, not only led Green to it, but designated it the remains of the Tautoro marae, one of the main traditional marae of Aukena and it did face the setting sun, as described by Laval (1938:6). Emory (1939:27), without visiting the island, was "doubtful that anything remains of this marae." The site, consisting today of only a pavement 9-by-18 $\mathrm{m}$ in size, was designated GA-3 (Green and Weisler 2000: Fig. 18).

Moerenhout (1837) also explored the southeastern coast of the island and beyond Te Ana-o-tiki where he reported finding a valley containing only five or 
six habitations. In advancing toward the east, however, he found to his astonishment "several families who were living in the shallow excavations of the mountain, without other furnishings than several armfuls of dry grass and mats." Buck wrongly allocates his description to Akamaru (1938:228).

The 1959 excavations were directed toward exploring two items mentioned by Moerenhout. The first was a brief but productive excavation in one of the shallow overhangs in the cliffs, which he had observed as having occupants. One such site was at the extreme eastern end of the flat, on the land called Ko'iovao, though it was probably not one of those actually seen by Moerenhout. Since it was his description that led to Green searching for this tiny shelter to excavate, the site, designated GA-2, was called Moerenhout's Cave.

The main cave, with its rear opening and passageway, was known as Te Ana Putarua (Laval 1938: Pl. XIV). In 1959, Mangarevans referred to it as Te Ana Pu. The fallen mass of rocks which Moerenhout observed had apparently been more recently organized into a broad roadway, probably during the Mission period, but this has again fallen into disrepair, a narrow trail making use of the remains. Before commencing excavation, Green and associates cleared the entire eastern floor of the cave of these surface rocks, exposing the underlying sandy midden deposit, and mapped it (Fig. 8). The site, called Te Ana Pu after the current name of the cave, was designated GA-1.

The four coastal flats, two in the central portion of the island joined by the passageway through the cave and two along the western end of the island, constitute the main land on Aukena suited to habitation. The eastern portion of the island, with its extremely rough and rocky coastline, is not suitable for long-term habitation, although two small rockshelters were recorded there (Weisler 1996b:67-68).

Aukena is first mentioned in the traditional history of Mangareva at the time of the distribution of land to heirs of Anua-motua, an event placed genealogically at about A.D. 1375 (Buck 1938:28). By this period in the traditions, organized settlements are indicated for several districts on Mangareva, and at least one each on Akamaru and Taravai, the three main islands. However, it was not until ca. A.D. 1550, during the rise to power of Apeiti - as the first in the senior line to achieve recognition as principal chief over all the districts - that a district chief is mentioned for Aukena. This chief was Honu-a-keroiti, who lived at Veroto, a subdivision of the land of Ko'eovao (Ko'iovao) located directly in front of the cave of Te Ana Pu (Buck 1938:48).

Aukena later became one of those islands to which defeated people ('uigaraga), or the losing chief and his supporters, fled after a battle. This is well documented for the reigns of Te Arariki Tea, Te Arariki Pagu, and their sons, some seven or eight generations ago, or A.D. 1675-1700. At that time Te Arariki Tea was specified as living in exile on the land of Ko'iovao (Buck 1938:78). The traditional accounts thus imply that Aukena was permanently settled later than the three other main islands and was never as important or as desirable a place as the other three main islands in the group.

\section{GA-1, Te Ana Pu}

Three 2-by-2-m squares and two intervening baulks were excavated along the eastern side of the cave (Fig. 8). Removal of the cultural deposits proceeded by 


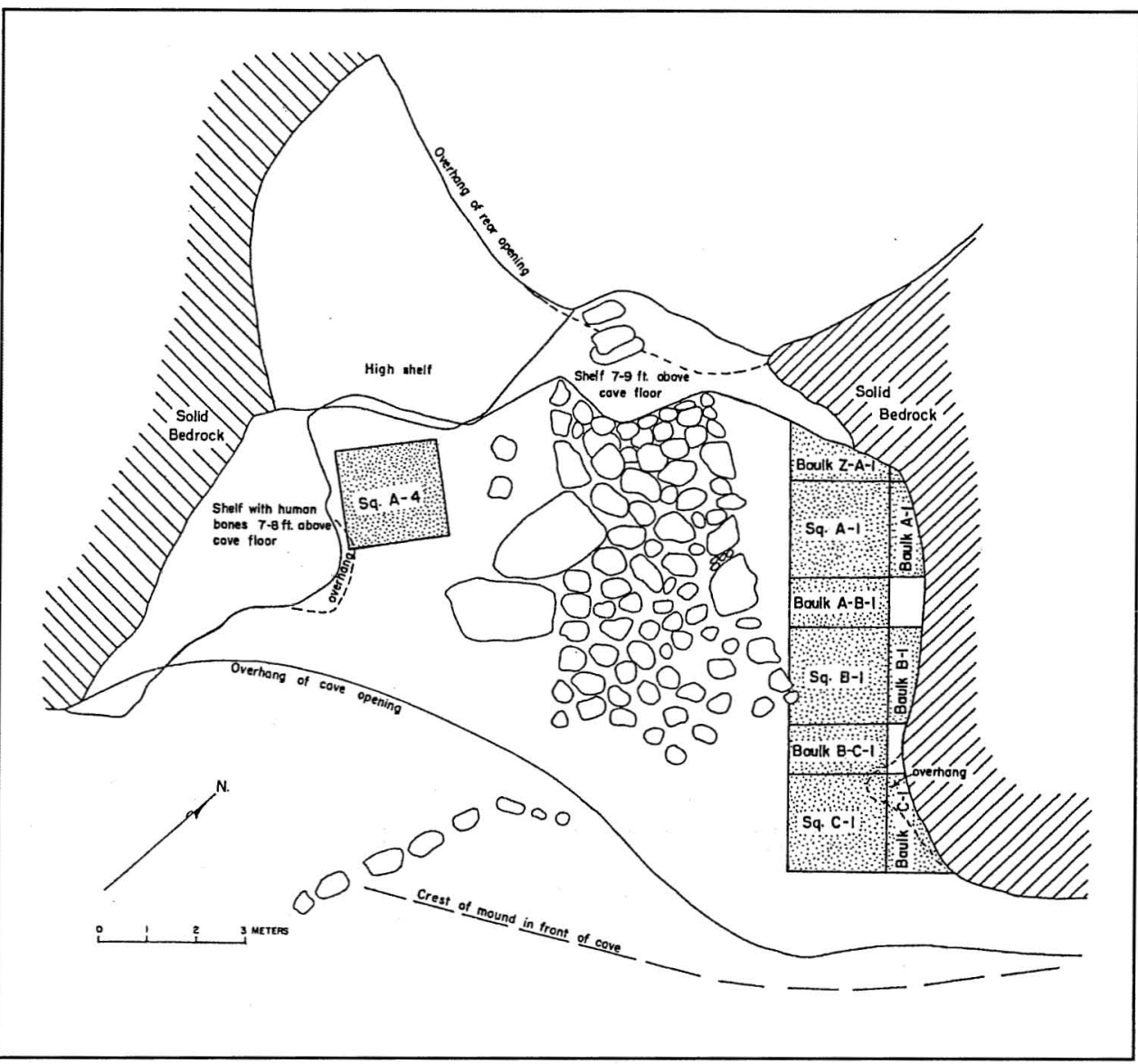

Fig. 8. Plan of rockshelter site Te Ana Pu (GA-1) on Aukena Island, Mangareva, showing location of excavation squares and stone ramp leading down from the north entrance through the site toward the adjacent coastal flat.

stratigraphically controlled layers until a sterile white beach sand was encountered. On the opposite side of the cave another $2 \mathrm{~m}^{2}$ (designated Square A-4) was opened, but the deposits proved shallow with few artifacts.

Overall stratigraphy was not as clearly defined as at GK-1 on Kamaka, but better defined than at GK-2. The clearest stratification occurred in Square B-1, from which a charcoal sample for dating was taken; Figure 9 illustrates the general sequence.

The cave floor was occupied temporarily as evidenced by lenses of fish and bird bone in Layer D (Bed 2). The more intensive occupation following later was concentrated at the front of the cave in Square C-1, but also occurred in Square A-I represented by the medium black deposits. At the end of this interval, clean beach sand was hauled in to provide a new living floor (Bed 3 in section, Fig. 9). The thin charcoal lens that accumulated directly on top of this floor dated to $520 \pm 80$ B.P. (Table 1, sample I-193). Consequently, the floor (Bed 3) and the lower accumulation of ash and bird bones-signaling the first use of this portion 


\section{Site $G A-1$}

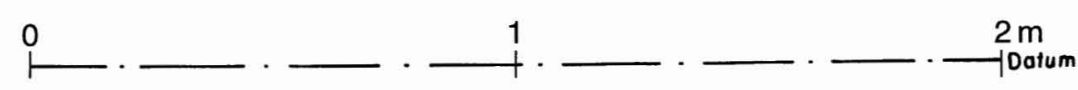

\section{Stratigraphic Section - Southeast Wall}

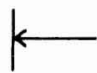

Square $B-I$

C

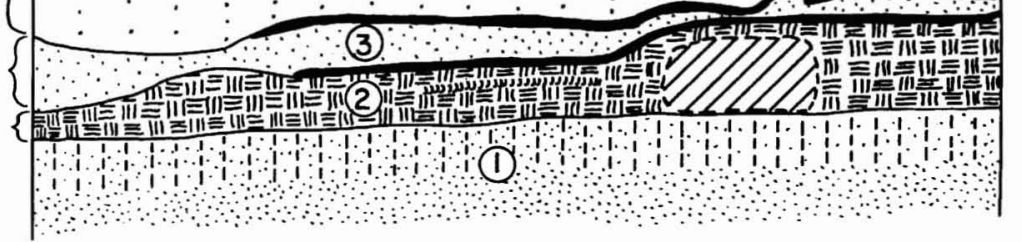

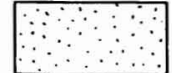

White

Beach Sand

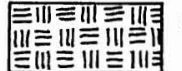

Compact Brown Clay

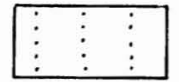

Warm
Sand

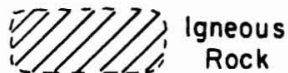

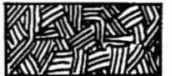

vory Block Sand

and Charcoal

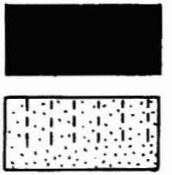

Band of

Charcoal

Silt Mixed With

White Beach Sand

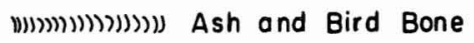

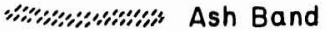

Fig. 9. Southeast profile of Square B-1, site GA-1, Aukena Island, Mangareva, showing layers and location of radiocarbon age determination.

of the cave - predates the mid-fifteenth century, considering the mean of the age determination.

This approaches in age the late fourteenth-century estimate for Aukena's occupation derived from oral tradition outlined above. Layer B, divided into B1 and B2, represents major and intensive occupation in the cave, probably in the 
sixteenth or early seventeenth century, or within the period of permanent settlement as also indicated in the traditional history.

Layer A contained pre-contact Polynesian artifacts, which exhibit none of the features characteristic of the final period of indigenous settlement, suggesting that occupation ceased before the period of European contact. The few European artifacts in the layer were undoubtedly deposited during either the Mission period or more recent periods. Layer A probably dates to before the mid-eighteenth century corresponding to similar materials from Kamaka, except for its upper surface which contained European artifacts.

\section{GA-2, Moerenhout's Cave}

Situated at the narrow coastal flat about $15 \mathrm{~m}$ from the sea, GA-2 is an overhang shelter with a protected area $2.5 \mathrm{~m}$ deep and $3 \mathrm{~m}$ wide. Although the surface deposits had been recently disturbed by pigs, the top $20-30 \mathrm{~cm}$ of deposit was a rich black layer of midden containing large pieces of pearl shell. In one corner, at the base of this layer, a white beach sand appeared, suggesting either a storm deposit, or more likely indicating that the beach sand had been imported to make the shelter more suitable for habitation. Sifting of these deposits produced a small collection of fishhooks which, stylistically, date to before the mid-seventeenth century. Consequently, the site, in relation to its fishhooks, probably dates between A.D. 1650 and 1750, although ethnohistory might extend its range to 1837.

\section{EXCAVATIONS ON MANGAREVA}

As the largest island, Mangareva is the obvious choice for locating layers dating to the period of initial settlement (see also Weisler 1996b:70), although in 1959 there was some difficulty in finding artifact-rich rockshelters suitable for excavation. Midden deposits occurred along most of the coastal flats, but in general they lacked depth and were frequently mixed with European artifacts. Throughout the last 1000 years or so, steady progradation of the coastal flats has occurred and the earlier sites may lie buried some distance inland from the present shoreline, unmarked by surface debris.

The traditional history provided by Buck (1938) mostly concerns the island of Mangareva where many of the events recorded are said to have occurred. However, only a single reference was made to the land of Kape'ure, in the district of Angakuku, on which excavations were conducted. This tradition referred to Moiume, a chief of Apeakava and owner of Kape'ure, who, at about A.D. 1775, was provoked into war as a result of an incident while tilling this land (Buck 1938:86-87).

\section{GM-1}

On this land one rockshelter (designated GM-1) was discovered along the base of high cliffs, several hundred meters from the sea near Taku village. The overhang shelter measured over $46 \mathrm{~m}$ long and of variable width. The inland portion of this 
shelter, $26 \mathrm{~m}$ in length, was sufficiently free from rockfall to be habitable, while the other portion had served as a burial area.

No record of prior archaeological investigations is known for this locality. Despite some archaeological survey in 1959, no other sites were found in the immediate area. Three 2-by-2-m squares were staked out in the habitable portion of the rockshelter and because of the lack of much cultural material, only two of the squares were excavated to sterile subsoil. Observable stratification of the deposits did not occur below the top layer, so that the remaining cultural deposits were removed in two arbitrary levels.

In summary, a homogeneous refuse deposit, 90-100 cm thick, accumulated in this shelter during the prehistoric period, largely as a result of cooking activity. Because it contained only a few artifacts, and the midden reflected the local marine ecology, in 1959, it proved singularly uninformative culturally.

\section{CORRELATION OF EXCAVATION SEQUENCES}

From excavations on three islands, we present a single set of intervals that are broadly applicable for the entire group. The archipelago is small and changes in any portable artifact sequence for each island-none of them more than a few hours apart by canoe-should be broadly contemporaneous throughout the group. Intra-archipelago differences that occur during any one period from one island or site to the next may be explained, in part, by variations in the local ecology. Such variation in response to the local ecological setting is well illustrated by the shell portion of midden samples from the different sites. It also serves to explain the high frequency with which fishhooks, for instance, were recovered from Kamaka.

The final correlation of the sequences from the six excavated sites discussed above is summarized in Figure 10. It is based on three factors: (1) selection of GK-1 and use of layer contents and floors to form a sequence to which other sites have then been correlated; (2) a general interpretation of the site formation processes - both cultural and natural - represented by each sequence, and dating of some deposits by the presence of European artifacts or the analysis of radiocarbon age determinations, all permitting a rough correlation between the various layers and levels of sites; and (3) a sharpening of these rough correlations wherever possible by identifying the periodic stylistic changes in fishhook features at GK-1, and equating similar assemblages from the other sites to those of that period. The correlation between some layers in sites is stronger than in others. Although various alternatives present themselves, choices were necessary and usually resolved by dependence on the fishhook evidence, the only artifact class encountered in quantity in all but two sites.

Only a small amount of material from the first period, represented by Layer $J$ at site GK-1, was recovered (Fig. 10). Thus whether it differed significantly from the assemblage in the layers immediately above is something of an open question. However, the artifact assemblage from Layer I of GK-1, particularly in fishhooks, forms a more complete assemblage. A few items similar to this appear at the base of GK-2, but not elsewhere suggesting that none of the other sites contain any layers with assemblages of this age. The first assemblage of GK-1, therefore, which is well recorded in other sites, is Layer H. It is also found in the lowest 


\begin{tabular}{|c|c|c|c|c|c|}
\hline \multicolumn{3}{|c|}{ Kamaka } & \multicolumn{2}{c|}{ Aukena } & Mangareva \\
\hline GK 1 & GK 2 & GK 3 & GA 1 & GA 2 & GM 1 \\
\hline & $\begin{array}{c}\text { Clay layer } \\
\text { A Surface } \\
\text { Floor I }\end{array}$ & Bed 12 & Foadway \\
\& \\
B
\end{tabular}

Fig. 10. Correlation of sequences from the six excavated sites on Mangareva.

layer of GK-2, and in the lowest layer of GA-1. At GA-1 this assemblage also appears in Layer B contexts, and where stratigraphically separable, is designated as $\mathrm{B}_{2}$.

Fishhooks comprising these mid-sequence forms are fully described in Green (1960) and have now been illustrated in Green (1998: Fig. 14) and Weisler and Green (2001, Fig. 31.2). They include the wiggly shank jabbing hook, the angular incurved shank hook, the early acute recurved point tip hook with a shorter tip leg, and the outcurved upper shank leg hook. A detailed manuscript on them, along with analysis of the fish bone and other faunal collections which accompany them, has been prepared for eventual publication (Weisler and Green n.d.).

Sufficient change occurred in the fishhook forms between Layer $\mathrm{H}$ and those of $F$ and $G$ at GK-1, that the correlation of these latter layers with those indicated 
in Figure 10 for GK-2, GK-3, GA-1, and GA-2, seems reasonable. In the case of the latter two sites on Aukena, the fact that the type of fishhooks recovered from the final period of GK-1, and also well known from ethnohistorical collections, does not appear in these two sites, strongly suggests that they were already abandoned at this date.

A final prehistoric period is based principally on sites on Kamaka, though it is likely that some of the deposits of GM-1 belong here. At this time an ethnographically known type of Mangarevan fishhook is present. This acute recurved point tip fishhook with the point leg as long or longer than the shank leg, and with a rearward projecting knobbed head type, are illustrated both by Buck (1938:51b) and by Green (1998: Fig. 14, middle row) and Weisler and Green (2001, Fig. 31.3). This prehistoric assemblage continues on into an even more brief early contact period, represented by Layer B at GK-1, in which a piece of scrap iron occurs - probably for an adze. Layer A at GK-2 and GK-3, may either belong to this period, as shown in Figure 10, or may be slightly earlier, correlating instead with Layer C of GK-1. Finally, either occupation or construction evidence belonging to the Mission and later periods of European contact and/or deposits representing complete abandonment of the sites, occurs at all but GA-2, and here recent disturbance by pigs has probably obliterated this surface deposit.

\section{LOCAL IMPLICATIONS FROM THE PARTIAL MANGAREVAN SEQUENCE}

In keeping with the archaeological pursuits of the time which were focused on building culture-historical sequences from artifact-rich deposits at stratified sites, the 1959 excavations in Mangareva specifically targeted rockshelter sites thought to contain the necessary components for formulating a chronological framework for the island group. The major excavations were conducted at Kamaka and Aukena islands, both small and with limited terrestrial resources. Indeed, there are no dependable water sources on these islands and arable land is at a premium. Consequently, it is unlikely that the earliest habitation deposits would be encountered at any sites on these islands. Like settlement patterns on low coral atolls, the smallest islets of each atoll can be viewed as resource locales for capturing birds and for staging fishing sorties on the adjacent oceanside reefs (see Weisler $1996 b, 2001)$ - a situation analogous to Kamaka. Aukena, at $1.5 \mathrm{~km}^{2}$, with rugged topography and limited coastal flats, is not an ideal locale for colonization sites. However, the obvious location for finding the earliest sites is almost certainly Rikitea village on Mangareva. As pointed out by Weisler (1996b:70), the springs issuing at the base of the slopes, on the inland margin of deep alluvial soils, provided an ideal locale for early settlement. This is suggested further by the gley soil (Tercinier 1974) located there, which at initial colonization, was probably a swampy area suitable for planting aroids. This area provides easy access to the lagoon shore and is situated in the lee, protected from the southeast trades. We believe the "missing centuries" of the Mangarevan sequence will be found there.

Based on the chronological sequence for Henderson Island, where numerous sites contain black-lipped pearl shell, Pinctada margaritifera (Weisler 1993:184187, $1997: 165)$, vesicular basalt oven stones and medium-grained industrial stone (Weisler 1995:394, 1997:164-165), and certain plants (Hather and Weisler 
2000; Weisler 1997: Table 9.2) - most imported from Mangareva beginning as early as the ninth century A.D. (Weisler 1995:389, 1997: Table 9.3) - it is clear that sites predating the twelfth century on Mangareva must surely exist. The fact that the earliest four centuries of human occupation on Mangareva await definition is suggested further by the faunal sequence at GK-1 and GK-2, which contain the earliest known habitation evidence, yet only three bones of extinct or extirpated land birds (Steadman and Justice 1998:93). Although relatively more bird bones were identified from the lower layers in these sites, the faunal sequence does not have the "signature" of early habitation sites identified elsewhere on Oceanic islands (e.g., Steadman and Rolett 1996; Steadman et al. 1994). That is, relatively large quantities of extinct or extirpated land and sea bird bones in the earliest deposits with upper, younger layers containing progressively fewer bird bones (see Emory and Sinoto 1961:18 for a classic example). Based on the evidence discussed here, we believe that two to four centuries of Mangarevan prehistory awaits definition with earliest human evidence possibly predating A.D. 800 .

The evidence for interaction between Mangareva and the Pitcairn group is diverse beginning about A.D. 1000 and lasting to at least the mid-fifteenth century (Weisler 1995), with an array of commodities documented. Stone and shell resources have been mentioned above, while cultigens, such as giant swamp taro (Cyrtosperma chammisonis) and banana (Musa sp.) and several other species of economic value (e.g., Cordyline, Aleurites, and Hibiscus) were introduced to Henderson during the period of inter-island voyaging (Hather and Weisler 2000; Waldren et al. 1999; Weisler 1997:165). While we do not know whether the plants were introduced directly from Mangareva to Henderson-they could have come via Pitcairn - the original source was undoubtedly Mangareva.

The exporting of industrial stone, pearl shell, and plant materials from Mangareva to the Pitcairn group was well developed during nearly five centuries beginning about A.D. 1000. One polished basalt flake, a surface find from the Aukena rockshelter (GA-1), and a surface collected adze preform midsection from Agakauitai Island originated from the Tautama source on Pitcairn (Woodhead and Weisler 1997) and provides the first archaeological evidence in Polynesia of two-way transfer of commodities in prehistory. Figure 11 summarizes our current understanding of the commodities involved in the Mangareva-Pitcairn group interaction sphere from ca. A.D. 1000 to ca. A.D. 1450, updating those figures found in Weisler (1996a, 1998b).

We also know that by the thirteenth century, Mangareva was linked to the Eiao basalt source in the Marquesas and, additionally, may have had indirect contact with the Society Islands (Weisler 1998a). A Tahitian-style Duff type 1A adze collected as a surface find on Mangareva Island, was geochemically similar to a basalt source on Ra'iatea, Society Islands, further documenting long-distance ties with Mangareva (Weisler and Green 2001). Three modes of contact-withinisland group, close inter-archipelago, and far inter-archipelgo-are also supported by similarities of fishhooks between the Cooks, Australs, Mangareva, the Marquesas, and Easter Island (Weisler and Green, 2001). The middle period (A.D. 1200-1450), characterized by long-distance interaction, especially with the Marquesas and attested by fishhooks, harpoons, and adzes, is now relatively well 


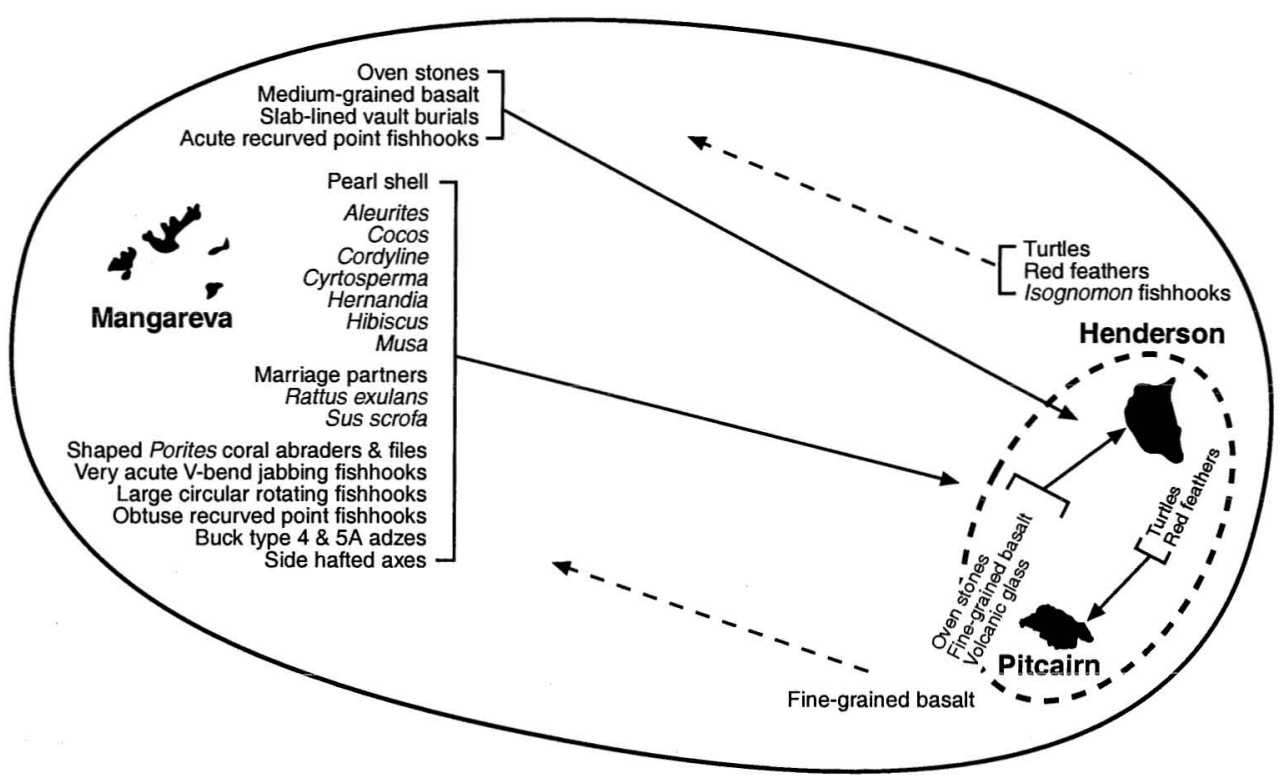

Fig. 11. The commodities of the Mangareva-Pitcairn group interaction sphere operating ca. A.D. $1000-1450$.

known for the Mangareva sequence, although the first few centuries of discovery and colonization await documentation, and can only be inferred indirectly from Henderson Island.

\section{DATING OF AND GEOGRAPHIC EXPANSION INTO SOUTHEAST POLYNESIA}

Kirch (1986), rightfully in our view, called for all of us to rethink East Polynesian prehistory. This is done here from a southeastern Polynesian perspective using new information about that region and its settlement. What we are challenging is the proposition of a direct voyage from the Marquesas to Easter Island, ignoring Mangareva, Pitcairn, and Henderson.

Hatanaka (as quoted in Sinoto 1978:103), in proposing research on some of the culturally atypical atolls of the eastern part of the Tuamotu chain, long ago expressed the view that: "Both Pukarua and Reao, which were settled by Polynesians in the early period, are linguistically different not only from the major East Polynesian islands but also from many of the Tuamotu islands. Also, these two atolls were influenced by the movement of Polynesians eastwards [to Mangareva and Easter Island]." The view adopted here is a rather similar one more recently put forward by Irwin (1992:198 and Fig. 80) based on voyaging patterns and a close proximity analysis of mutual accessibility among the Polynesian islands. As Irwin's diagram shows, what one has is a movement out of the Society Islands cluster and along the western part of the Tuamotuan chain at the base for a Y pattern. One branch from the Southern Cook Island-Society Island base leads north to the Marquesas and then further north-northwest to Hawai' $i$, whereas the other branch trends southeast to the Mangarevan and Pitcairn groups and then east to Easter Island (Fig. 12). 


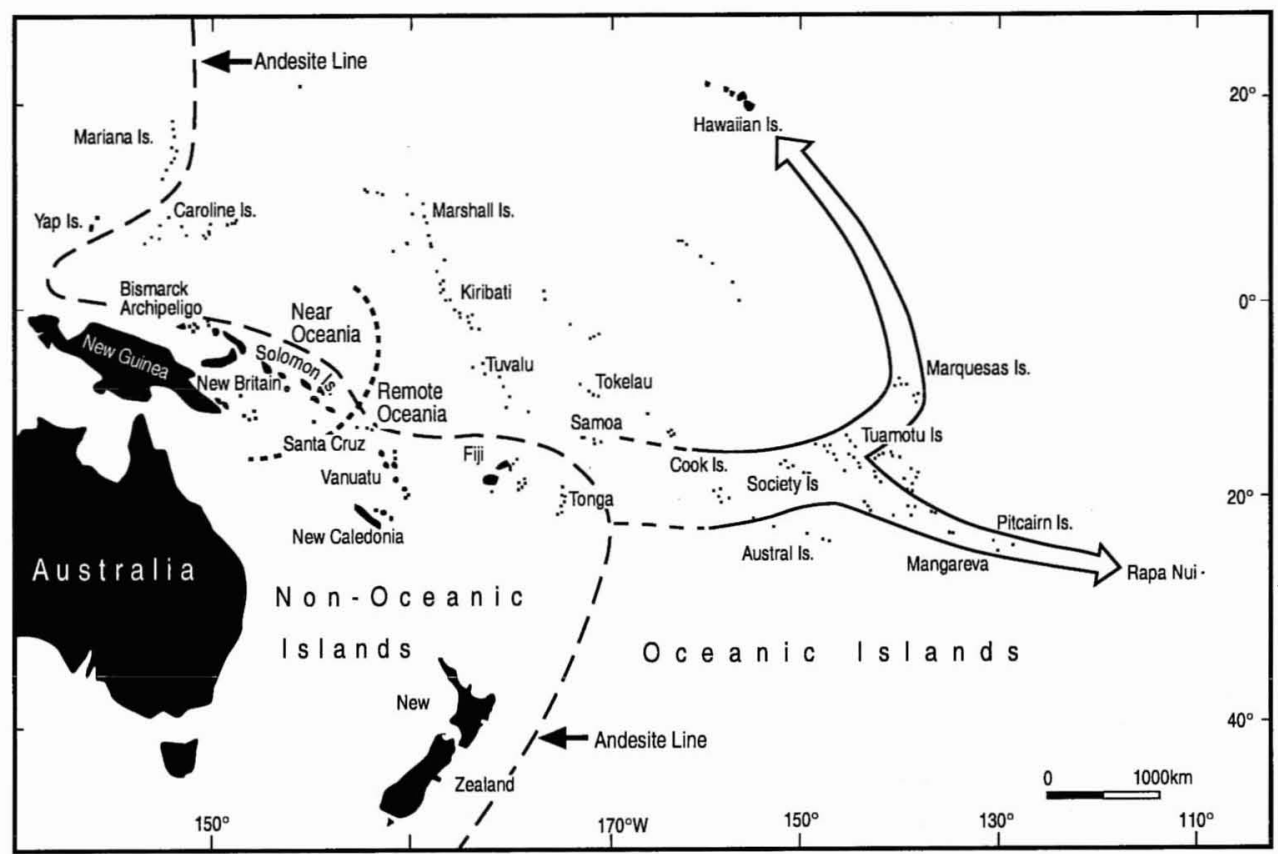

Fig. 12. The Y pattern settlement model of East Polynesia.

Unfortunately, dating for the initial colonization and established settlement of the Marquesan group currently remains imprecise (Rolett 1998:55-57). However, we tend, following the extensive reviews and critical re-evaluations of both Rolett and Anderson et al. (1994:34), to believe that a period around the middle of the first millennium A.D. is the most likely. Moreover A.D. 700-900 is entirely consistent with the dating employed here for the colonization of Hawai' 1 , Henderson, and Easter Island outlined below, and with a minimal dating for Mo'orea in the Society Islands of some 1200 to 1400 years ago (Green 1996:217; Kirch $2000: 232-234)$. On the basis of recent reviews using archaeological, astronomical, and palynological evidence, the northern branch of the $\mathrm{Y}$ pattern ends in the successful colonization and continuing settlement of the Hawaiian group in the period A.D. 700-900 (Masse and Tuggle 1998:234), and not much earlier as was once thought.

Along the southeastern and eastern branch of this Eastern Polynesia Y pattern, the firmest case for colonization and continuing settlement of an island is that for the makatea landform of Henderson in the Pitcairn group at A.D. 700-900 (Weisler 1998a:77-79), and by inference (as above) of the Mangarevan group at the same time. A date for initial occupation on Henderson as early as A.D. 700 is a distinct possibility (Weisler 1998a:84).

For Easter Island, Martinsson-Wallin and Wallin (1998:183; see also Green 1998:102-103) set its Settlement period age in the interval A.D. 800-1100. Green (2000a) has also reviewed Flenley's (1996) most recent interpretation of the Rapanui pollen core records. Whereas the KAO1 core first analyzed had signaled a supporting date for the first locally specific forest clearance event due to 
human disturbance at ca. 1200 B.P. (i.e., A.D. 750) (Flenley 1996:135, 140), the $\mathrm{KAO} 2$ core from well out in the large Rano Kau crater indicates that a general date for an initial and wider human impact on the environment might have occurred some centuries earlier, perhaps the sixth to eighth century A.D. (Flenley 1996:137-139 and Table 1; Green 2000a: 74).

In short, archaeology and palynology from Hawai' $i$ and Easter Island plus archaeology on Henderson strongly support an assessment that the two end points of the East Polynesian Y pattern witnessing human colonization lies in the interval A.D. 700-800. It arises out of a Y base in the Society Islands, which predates A.D. 600 , and in the Southern Cook Islands, it should be even earlier.

A recent linguistic analysis of numerous lexical doublets in the Mangarevan languages by Fischer (2001) and yet further refinement of Eastern Polynesian subgrouping based upon it, opens up a further and rather enticing prospect. Fischer proposes that "Original Mangarevan (before a period of intensive contact with Marquesic speakers) is to be aligned with Rapanui in a subgroup (Proto South-Eastern Polynesian) separate from Central Eastern Polynesian" (Fig. 13). By inference that subgroup would also include the extinct and unknown language of the Pitcairn group (including Henderson), and some of the "atypical" eastern Tuamotu languages. While Fischer believes its dating should perhaps be earlier, firm age estimates for this postulated subgroup currently rest on the ca. A.D. 700800 ages for first human occupation of Easter Island and Henderson (and by the inference of interaction, Mangareva as well). What Fischer terms a "a major invasion," which almost engulfed Mangareva and so completely transformed aspects of its original language that it currently also exhibits innovations that have until now placed it in the Marquesic subgroups, is a subsequent event.

Archaeological evidence for such contact and cultural influence is strongly attested to in the Mangarevan sequence and dated to the A.D. 1000-1450 interval (Weisler 1998b; Weisler and Green 2001). It would seem it was at this time that

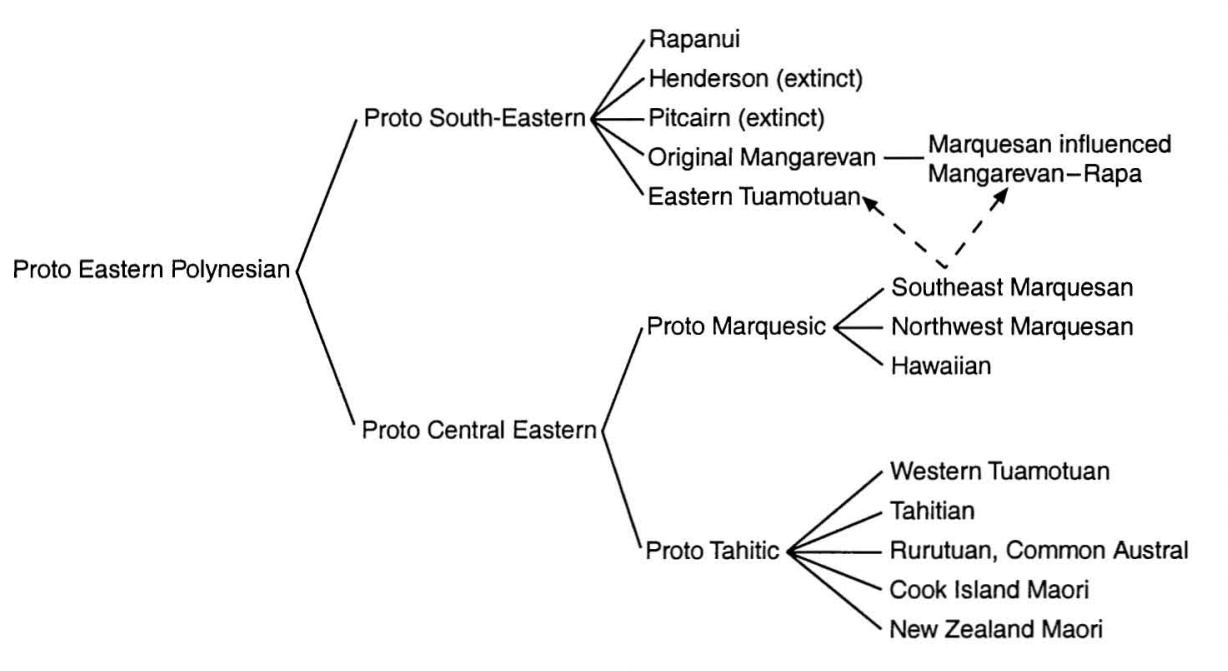

Fig. 13. Linguistic subgrouping of East Polynesia (after Fischer 2000, with additions). 
Rapa in the southernmost Australs was probably also settled, as the language is an offshoot of the Marquesan influenced Mangarevan language to which it is very closely aligned (Fischer 2000:110, fn. 4; Green 1966:27).

The Easter Island connections with and initial origins within the MangarevanPitcairn interaction sphere have been fully developed by Green (1998, 2000a) using multiple lines of evidence from not only archaeology but oral tradition, historical linguistics, biological anthropology, and faunal evidence. The dated portable artifact comparisons on which Green has relied, however, were drawn in both instances from Mangarevan and Easter Island assemblages largely assigned to the twelfth and thirteenth centuries A.D., though they probably accurately reflect aspects of an earlier stage. Although little is known in relation to diagnostic artifacts of either place in the period A.D. 800-1100, for the twelfth century A.D. and after, numerous parallels are in evidence in a number of artifact categories common to Mangareva and Easter Island (Green 1998:103-107). Later connections also have to do with the Mangarevan marae and the Easter Island ahu structures (Green 2000b).

\section{CONCLUSIONS}

The evidence indicating that the Mangarevan prehistoric sequence extends to A.D. 800 or before is presented in the context of a directly attested archaeological portion described above going back to A.D. 1100-1200. The basis for constructing that sequence, principally from excavations on the very small and marginal islands of Kamaka and Aukena, is presented in summary form here and in full detail in Green and Weisler (2000). It has been clear for over 35 years that the Settlement period of the Mangarevan sequence was missed in the 1959 excavations (Green 1966:25), but it is only with Weisler's work on Henderson and his documentation of an interaction sphere within the Pitcairn and Mangarevan groups, that the approximate length of this missing interval has become apparent. With Weisler's (1996b) additional survey work on Mangareva, it is also more predictable where and how on the main island of Mangareva the relevant deposits might be found in Rikitea village and possibly in the eroding middens on the island of Taravai.

Once the extent of the Mangarevan sequence is in place and appropriately interpreted, a model for initial expansion into Southeast Polynesia out of the Society Islands-Tuamotus can be constructed for the period A.D. 600-800. Colonization followed closely by established settlement of Polynesian communities in that interval on Mangareva, Pitcairn, Henderson, and Rapa Nui proves to be highly consistent with the voyaging patterns predicted by Irwin. (1992) for Eastern Polynesia. What is encouraging is that this schema can also be shown to be highly compatible with the most recently proposed linguistic analysis of the Mangarevan languages by Fischer (2001) and his proposals for further refinement of East Polynesian subgrouping, and with the biological interpretation of skeletal materials from the region by Chapman (1998) and Stefan (2000) discussed in more detail in Green $(1998,2000 b)$ demonstrating the close linkages between the prehistoric populations of Easter Island, Mangareva, and the Tuamotu archipelago within Eastern Polynesia. It would appear that our understanding of southeastern Polynesian prehistory now stands on a firmer basis than it has previously, and 
what is required next is more fieldwork to fill in the gaps and further refine vital aspects of its cultural history.

\section{ACKNOWLEDGMENTS}

Green was assisted by Kaye C. Green and Lois and Donald McClain of Sea Island, Georgia, during some periods of the fieldwork in Mangareva. They are thanked both for their help and the company provided under what often proved to be difficult circumstances. Green spent late 1960 to early 1961 at the American Museum of Natural History (AMNH) when much of the initial laboratory processing was completed and the illustrations prepared. Funds for additional radiocarbon age determinations and support for study at the AMNH in 1997 were provided to Weisler by the University of Otago, Research Committee. Weisler thanks especially Paul Beelitz, Belinda Kaye, and Sharon Loetz for organizing the Mangarevan collections at the AMNH. Les O'Neill (University of Otago) and Joan Lawrence (University of Auckland) made additions to some of the figures originally prepared some 40 years previously.

\section{REFERENCES CITED}

Anderson, A., H. Leach, I. Smith, And R. Walter

1994 Reconsideration of the Marquesan sequence in East Polynesian prehistory, with particular reference to Hane (MUH1). Archaeology in Oceania 29:29-52.

Buck, P. (Te Rangi Hiroa)

1938 Ethnology of Mangareva. Honolulu: B. P. Bishop Museum Bulletin 157.

Chapman, P.

1998 An Examination of East Polynesian Population History. Ph.D. diss., University of Otago. Dunedin, New Zealand.

EMORY, K. P.

1939 Archaeology of Mangareva and Neighboring Atolls. Honolulu: B. P. Bishop Museum Bulletin 163.

EMORY, K. P., W. J. Bonk, AND Y. H. Sinoto

1959 Hawaiian Archaeology: Fishhooks. Honolulu: B. P. Bishop Museum Special Publication 47.

EMORY, K. P., AND Y. H. Sinoto

1961 Hawaiian Archaeology: Oahu Excavations. Honolulu: B. P. Bishop Museum Special Publication 49.

FisCHER, S. R.

2000 Preliminary evidence for Proto Austral, excluding Rapan, in Leo Pasifika: Proceedings of the Fourth International Conference on Oceanic Linguistics: 100-111, ed. S. R. Fischer and W. B. Sperlich. Auckland: The Institute of Polynesian Languages and Literatures.

2001 Mangareva doublets: Preliminary evidence for Proto-Southeastern Polynesia. Oceanic Linguistics 40:112-124.

FLenLey, J. R.

1996 Further evidence of vegetational change on Easter Island. South Pacific Study 16:135-141. (Kagoshima University Research Centre for the South Pacific.)

GreEn, Robert C.

1960 Preliminary report for the American Museum of Natural History on archaeological research in the Gambier Isles (Mangareva) July 2, 1959 to December 6, 1959. Manuscript on file, Central Library, University of Otago.

1961 Review of K. P. Emory, W. J. Bonk, and Y. H. Sinoto, Hawaiian Archaeology: Fishhooks. Journal of the Polynesian Society 70:139-144.

1966 Linguistic subgrouping within Polynesia; the implications for prehistoric settlement. Journal of the Polynesian Society $75: 6-38$.

1967 Settlement patterns: Four case studies from Polynesia, in Archaeology at the Eleventh Pacific Science Congress: 101-132, ed. W. G. Solheim II. Honolulu: Asian and Pacific Archaeology Series 1. 
1996 Settlement patterns and complex society in the Windward Society Islands, Retrospective commentary from the 'Opunohu Valley, Mo'orea, in Mémoire de Pierre Mémoire d'Homme, Tradition et archéologie en Océanie: 209-227, ed. M. Julien, M. Orliac, C. Orliac, B. Gérard, A. Lavondés, and C. Robineau. Collection Homme et Société 23. France: Université de Paris I, Panthéon-Sorbonne.

1993 Tropical Polynesia prehistory - Where are we now?, in A Community of Culture: 218238, ed. M. Spriggs, D. E. Yen, W. Ambrose, R. Jones, A. Thorne, and A. Andrews. Canberra: Occasional Papers in Prehistory 21.

1998 Rapanui origins prior to European contact: The view from Eastern Polynesia, in Easter Island and East Polynesian Prehistory: 87-110, ed. P. Vargas Casanova. Santiago: Universidad de Chile, Facultad de Arquitectura y Urbanismo, Instituto de Estudios Isla de Pascua.

2000a Religious structures of southeast Polynesia: Even more marae later, in Essays in Honour of Arne Skjolsvold 75 Years: 83-100, ed. P. Wallin and H. Martinsson Wallin. Oslo: KonTiki Museum Occasional Papers 5.

$2000 \mathrm{~b}$ Origins for the Rapanui of Easter Island before European contact: Solutions from holistic anthropology to an issue no longer much of a mystery. Rapa Nui Journal 14:71-76.

Green, Robert C., AND M. I. WeisLeR

2000 Mangarevan Archaeology: Interpretations Using New Data and 40 Year Old Excavations to Establish a Sequence from 1200 to 1900 A.D. University of Otago Studies in Prehistoric Anthropology 19. Dunedin, New Zealand: University of Otago.

HATHER, J. G., AND M. I. WeISLER

2000 Prehistoric giant swamp taro (Cyrtosperma chamissonis) from Henderson Island, southeast Polynesia. Pacific Science 54:149-156.

IrWIN, G.

1992 The Prehistoric Exploration and Colonisation of the Pacific. Cambridge: Cambridge University Press.

KIRCH, P. V.

1982 Advances in Polynesian prehistory: Three decades in review. Advances in World Archaeology 1:51-97.

1986 Rethinking East Polynesian prehistory. Journal of the Polynesian Society 95:9-40.

1989 Prehistory, in Developments in Polynesian Ethnology: 13-46, ed. A. Howard and R. Borofsky. Honolulu, HI: University of Hawai'i Press.

2000 On the Road of the Winds, An Archaeological History of the Pacific Islands before European Contact. Berkeley, CA: University of California Press.

LAVAL, P. H.

1938 Mangareva, l'Histoire Ancienne d'un Peuple Polynesien. Paris: Librairie Orientale Paul Geuthner.

Martinsson-Wallin, H., and P. Wallin

1998 Excavations at Anakena. The Easter Island settlement sequence and change of subsistence?, in Easter Island and East Polynesian Prehistory: 179-186, ed. P. Vargas Casanova. Santiago: Universidad de Chile, Facultad de Arquitectura y Urbanismo, Instituto de Estudios Isla de Pascua.

Masse, W. B., And H. D. Tuggle

1998 The date of Hawaiian colonization, in Easter Island in Pacific Context South Seas, Proceedings of the Fourth International Conference on Easter Island and East Polynesia: 229-235, ed. C. M. Stevenson, G. Lee, and F. J. Morin. Los Osos, CA: Bearsville and Cloud Mountain Presses.

Moerenhout, J. A.

1837 Voyages aux îles du Grand Océan,... Paris: A. Bertrand.

Rolett, B. V.

1989 Hanamiai: Changing Subsistence and Ecology in the Prehistory of Tahuata (Marquesas Islands, French Polynesia). Ph.D. diss., Yale University, New Haven, CT. Ann Arbor: University Microfilms International.

1992 Faunal extinctions and depletions linked with prehistory and environmental change in the Marquesas Islands (French Polynesia). Journal of the Polynesian Society 101:8694.

1998 Hanamiai: Prehistoric Colonization and Cultural Change in the Marquesas Islands (East Polynesia). New Haven, CT: Yale University Publications in Anthropology 82. 
Rolett, B. V., And E. Conte

1995 Renewed investigation of the Ha'atuatua Dune (Nukuhiva, Marquesas Islands): A key site in Polynesian prehistory. Journal of the Polynesian Society 104:195-228.

Sinoto, Y. H.

1978 Preliminary report of archaeological survey on Reao Atoll, Tuamotu Archipelago, French Polynesia, in A Study of the Polynesian Migration to the Eastern Tuamotus-Preliminary Report: 102-181, ed. S. Hatanaka. Kanazawa, Japan: University of Kanazawa.

Steadman, D. W., and L. J. Justice

1998 Prehistoric exploitation of birds on Mangareva, Gambier Islands, French Polynesia. Man and Culture in Oceania 14:81-98.

Steadman, D. W., AND B. Rolett

1996 A chronostratigraphic analysis of extinction of landbirds on Tahuata, Marquesas Islands. Journal of Archaeological Science 22:81-94.

Steadman, D. W., P. Vargas, and C. Cristino

1994 Stratigraphy, chronology, and cultural context of an early faunal assemblage from Easter Island. Asian Perspectives 16:79-96.

STEFAN, V. H.

2000 Craniometric Variation and Biological Affinity of the Prehistoric Rapanui (Easter Islanders): Their Origin, Evolution, and Place in Polynesian Prehistory. Ph.D. diss., University of New Mexico, Albuquerque, New Mexico. Ann Arbor: University Microfilms International (UMI 9976375).

Stuiver, M., AND P. J. Reimer

1993 Extended ${ }^{14} \mathrm{C}$ data base and revised $3.0{ }^{14} \mathrm{C}$ age calibration program. Radiocarbon $35: 215-2320$.

SugGs, R. C.

1961 The Archaeology of Nuku Hiva, Marquesas Islands, French Polynesia. Anthropological Papers of the American Museum of Natural History 49(1). New York, NY: American Museum of Natural History.

Tercinier, G.

1974 Les sols de l'ile de Mangareva (Gambier): Étude pédologique témoin d'une ile haute de la Polynésie Française. Cashiers du Pacifique 18:341-357.

Waldren, S., M. I. Weisler, J. G. Hather, and D. Morrow

1999 The Non-native Plant Species of Henderson Island, South-central Pacific Ocean. Atoll Research Bulletin 463. Washington, D.C.: Smithsonian Institution.

WEISLER, M. I.

1993 Long-distance Interaction in Prehistoric Polynesia: Three Case Studies. Ph.D. diss., University of California, Berkeley.

1994 The settlement of marginal Polynesia: New evidence from Henderson Island. Journal of Field Archaeology 21 : 83-102.

1995 Henderson island prehistory: Colonization and extinction on a remote Polynesian island. Biological Journal of the Linnean Society 56:377-404.

1996a Taking the mystery out of the Polynesian 'mystery' islands: A case study from Mangareva and the Pitcairn Group, in Oceanic Culture History. Essays in Honour of Roger Green: 615629, ed. J. Davidson, G. Irwin, F. Leach, A. Pawley, and D. Brown. New Zealand Journal of Archaeology Special Publication. Dunedin, New Zealand: New Zealand Archaeological Association.

$1996 b$ An archaeological survey of Mangareva: Implications for regional settlement models and interaction studies. Man and Culture in Oceania 12:61-85.

1997 Prehistoric long-distance interaction at the margins of Oceania, in Prehistoric Long-Distance Interaction in Oceania: An Interdisciplinary Approach: 149-172, ed. M. I. Weisler, New Zealand Archaeological Association Monograph 21. Dunedin, New Zealand: New Zealand Archaeological Association.

1998 a Issues in the colonization and settlement of Polynesian Islands, in Easter Island and East Polynesian Prehistory: 73-86, ed. P. Vargas Casanova. Santiago: Universidad de Chile, Facultad de Arquitectura y Urbanismo, Instituto de Estudios Isla de Pascua.

1998b Hard evidence for prehistoric interaction in Polynesia. Current Anthropology 39:521-532.

2001 On the Margins of Sustainability: Prehistoric Settlement of Utrōk Atoll, Northern Marshall Islands. British Archaeological Reports International Series 967. 
WeIsler, M. I., AND Robert C. GReen

2001 Holistic approaches to interaction studies: A Polynesian example, in Australasian Connections and New Directions: Proceedings of the $7^{\text {th }}$ Australasian Conference, ed. M. Jones and P. Sheppard. Research in Anthropology and Linguistics Series 5: 413-453. Auckland, New Zealand: University of Auckland.

n.d. Faunal assemblages and fishing gear from Mangareva excavations spanning the period between 1200 and 1840 A.D. Manuscript, November, 1999.

WOODHEAD, J. D., AND M. I. WeisLer

1997 Accurate sourcing of basaltic artefacts by radiogenic isotope analysis, in Prehistoric LongDistance Interaction in Oceania: An Interdisciplinary Approach: 212-223, ed. M. I. Weisler. New Zealand Archaeological Association Monograph 21. Dunedin, New Zealand: New Zealand Archaeological Association.

\section{ABSTRACT}

A recently published archaeological sequence supported by information from six sites excavated in the Mangarevan group in 1959 is summarized in the context of additional data and current interpretations of the prehistory of southeastern Polynesia. The known part of the Mangareva sequence covers the period from ca. A.D. 1200 to the time of early nineteenth-century contact with Europeans, with its dating enhanced by four new radiocarbon age determinations plus four previous ones, all on samples collected in 1959. More recent information from archaeological investigations on nearby Pitcairn and Henderson islands, showing they formed part of a long-term interaction sphere with Mangareva, indicate that while the early part of the Mangareva sequence from ca. A.D. 800-1200 remains undocumented, buried cultural deposits for this interval probably exist within Rikitea village on the main island of Mangareva.

An A.D. 700-800 settlement for the Mangareva group is consistent with a similar age and origin for the first inhabitants of Easter Island, as aspects of the thirteenthcentury assemblages from both places are comparable. A similar age is also supported by several dates for an initial colonization of Henderson Island in this period. Recent linguistic reworking of the early subgrouping of Eastern Polynesian suggests Easter Island, Original Mangarevan, and probably the extinct Polynesian languages of Henderson and Pitcairn were the first in the region, placing the age of that subgroup around A.D. 700-800. A major secondary contact with Marquesan speakers who may have settled in Mangareva at A.D. 1100-1300, seems to have been the basis for changing it into a Marquesic language, of a form then taken to Rapa. The archaeology, biological relationships, and linguistic history of the region now provides a robust and consistent outline for the geographic expansion into Southeast Polynesia. Keywords: culture-historical sequence, Mangareva group, Southeast Polynesia, geographical expansion, radiocarbon dating. 